\title{
Strategic model for location selection of solar wood drying by applying TOPSIS
}

\section{Majid Azizi}

College of Agriculture and Natural Resources, University of Tehran, 16th Azar St., Enghelab Sq., Tehran, Iran

Professor, Faculty of Natural Resources, Wood and Paper Sciences and Technology Department

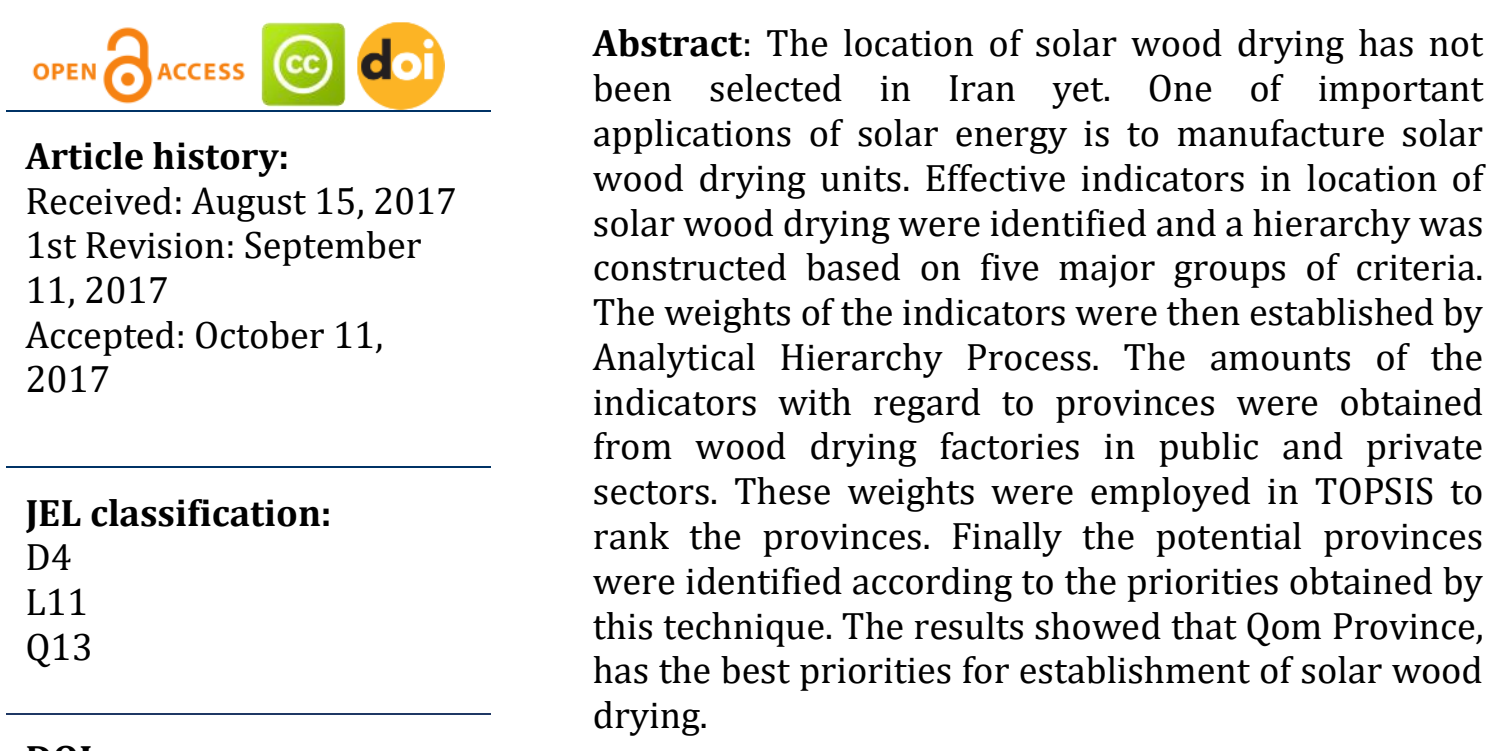

DOI:

10.14254/jems.2017.2-2.2

Keywords: solar wood drying, TOPSIS, Analytical Hierarchy Process, location, priority.

\section{Introduction}

One of the possible and valuable applications of solar energy is in wood industry and manufacturing solar wood dryer. In solar dryers, solar energy is used for drying material indirectly or directly and air flow helps to moisture displacement naturally or in an under controlled way which accelerate wood drying process. The solar drying kiln is the most cost effective way for the craftsman to get quality boards for wood working from green lumber. Iran has been located between 25-40 degrees of northern latitude and regarding solar energy receiving has highest level in the world. The amount of sun radiation is between $1800-2200(\mathrm{kWh}) / \mathrm{m}^{3}$ in a year which is higher than world average. In Iran more than 280 days are sunny which is very notable (www.suna.org.ir). Solar energy is one of the freest and cleanest sources of energy in the world which has no destructive effect on the environment. It has been used in various ways by the people for a long time. In the case of solar radiation for 40 days required energy for one century can be reserved. Thus by applying solar radiation concentrators along with the use of this free and clean and endless energy, the saving of fossil fuel consumption will also be possible. Today there are many band saw operators cutting boards from trees that grow in abundance in much of America. The solar kiln is the link between this resource and the shop. A wood kiln is any space used for controlling heat and humidity where lumber is dried. The solar drying kiln harnesses the free

Corresponding author: Majid Azizi

E-mail: mazizi@ut.ac.ir

This open access article is distributed under a Creative Commons Attribution (CC-BY) 4.0 license. 
energy of the sun. It operates on the regular cycle of day and night to prevent wood stress that can ruin lumber in other systems (Wilson, 2006). Solar drying is one of the important thermal applications, where solar energy can be utilized efficiently. Drying depends on the air ability to evaporate water (drying potential); hence its relative humidity is a key factor. The lower the relative humidity of the drying air, the more water of air evaporates from the product, resulting in lower final product moisture content. Drying potential is influenced by air temperature as well as relative humidity. Much work on solar energy has been concerned with the use of solar heated air (naturally or mechanically circulated) to remove the moisture from materials placed inside an enclosure where the heated air is blown past the material. Solar drying provides up to $50 \%$ reduction of final moisture content and drying time compared with air-drying (Helwa et al., 2004). Over the last few decades, much research and development has been conducted into the use of solar kilns for timber drying. This has led to the commercial use and availability of solar kilns in the timber industry over recent years (Desch \& Dinwoodie, 1996). The present study aims to identify the effective criteria on best site selection to establish solar wood drying units in Iran via TOPSIS.

Studies on site selection for wood production by Michael et al (1998), identified a number of factors affecting the selection decision. They clustered the criteria into cost, market distribution, lower production cost and non-tangible factors. McCauley and Caulfield (1990) specified the effective criteria for selection of an OSB (Oriented strand board) factory and developed a mixed integer programming model to determine the optimal location of the OSB sites.

The AHP method is based on three steps: model structure; comparative judgment of the alternatives and criteria; and synthesis of the priorities. In the literature, the main developments in AHP have been widely used to solve many complicated decision-making problems (Ishizaka \& Labib, 2011). For selecting the best wood panel, intensities of the criteria and sub criteria obtained. Then the wood panels have been ranked according to the AHP evaluation. The results indicate that the density of the product and its high intensity has the highest priority. The Ghazvin panel has the highest priority, and the moisture percentage criterion is very sensitive in comparison with other criteria (Azizi, 2012).

\section{Modeling the selection problem}

The modeling consists of three main stages, which are as follows:

\subsection{First stage}

For finding capable provinces of Iran to establish solar wood drying units 30 questionnaires were distributed among qualified people who were academic members (10\%), Industries and mines organization; planning and budget organization (14\%), members of furniture union (30\%) and owners of industries (46\%) and provinces which had no capability for establishing solar wood drying units were deleted. Capable Provinces which had appropriate site to establish solar wood drying units are as follow: Tehran, Qom, Khorasan Razavi, Markazi, Fars, Mazandaran, Isfahan, Ghazvin, Alborz. Climate changes is a limitation in this study. We studied the provinces in a stable situation regarding climate. The changes can be considered for future researches.

\subsection{Second Stage}

In order to analyze the candidate locations and identify the most preferred ones, the initial step is to identify the criteria. A comprehensive list of factors was prepared and a questionnaire was designed to evaluate their contribution in decision process in the case of Iran. This questionnaire was distributed among experts in Iran wood drying factories. The final set of the attributes was concluded via a Delphi method. A hierarchy of these factors was constructed to establish their weights, using Analytic Hierarchy Process (AHP). The pair-wise comparison matrices were completed by 20 experts from industry and academia. The individual judgments were directed towards consistency and the aggregated opinion was derived using TEAM- EC 2000. Figure 1 shows the hierarchy structure of the attributes influencing decision on selection of solar wood drying. 


\section{Figure 1: The hierarchy of criteria and sub-criteria}

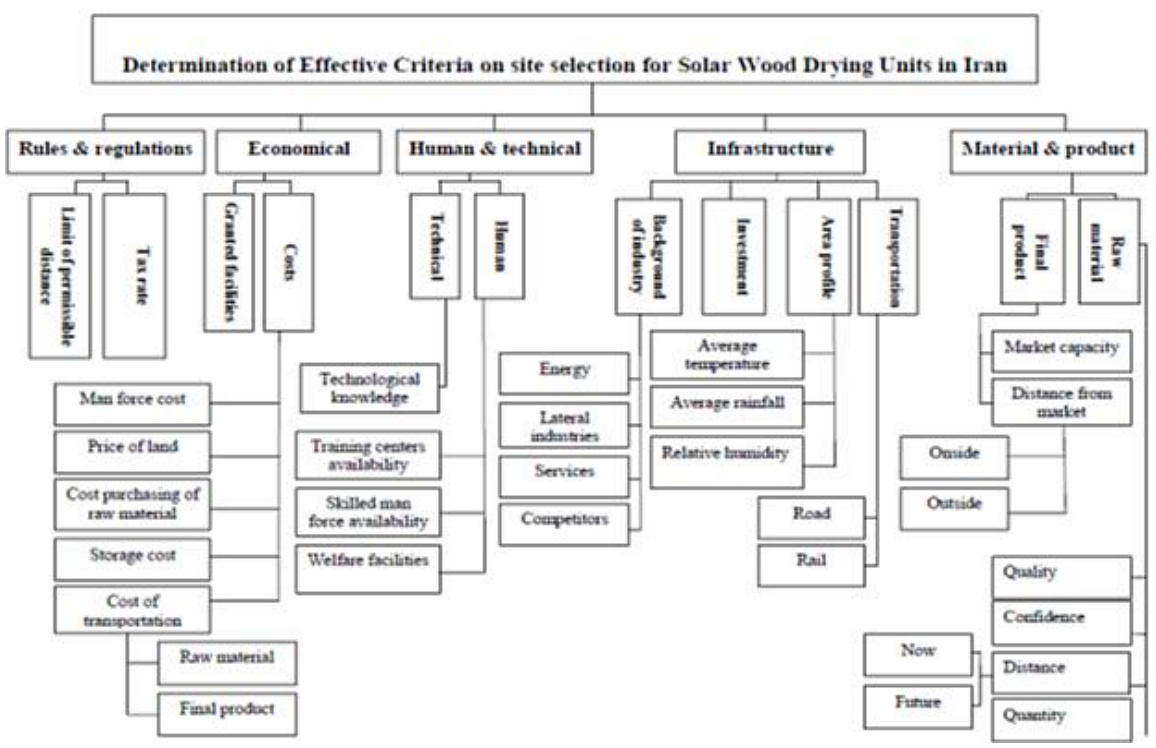

\subsection{Third stage}

In the third stage, the data for the attributes were collected from the alternative locations. For this, the questionnaires were presented to the managers of the neighboring factories. Then the Fuzzy Decision Making (FDM) (Memariani, 2000), software was used to rank the location because the data for certain attributes were either qualitative or imprecise. This software is base of on Fuzzy version of TOPSIS (Technique for order- preference by similarity to ideal solution). It incorporates besides quantitative information, the imprecise (Fuzzy numbers) and qualitative (linguistic) data. Figure 2 shows the description of the problem in FDM.

\section{Figure 2: Description of the problem in FDM}

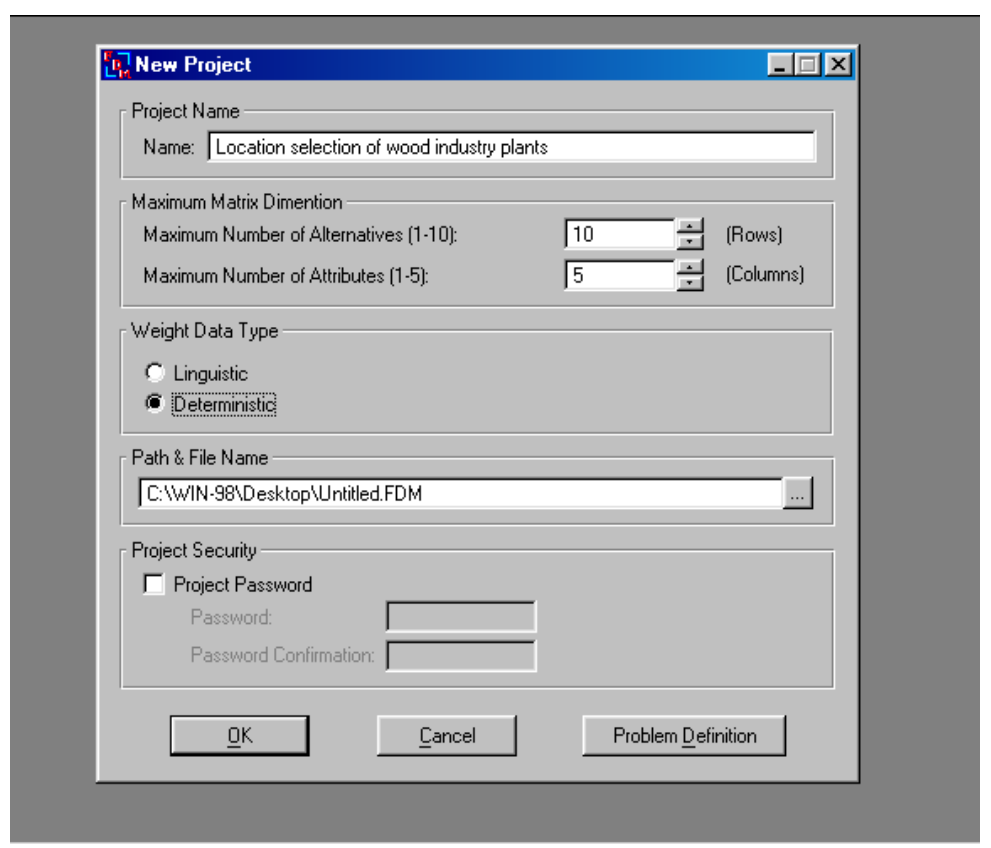

Table 1 shows the weighing value of the attributes influencing decision on selection of provinces for solar wood drying. 


\begin{tabular}{|c|c|c|c|c|c|}
\hline Row & Criteria & $\begin{array}{l}\text { Form of } \\
\text { data }\end{array}$ & $\begin{array}{l}\text { Weighing } \\
\text { value } \\
\text { (Global) }\end{array}$ & $\begin{array}{l}\text { Kind of } \\
\text { criteria }\end{array}$ & Description \\
\hline 1 & $\begin{array}{l}\text { Raw material \& product: raw } \\
\text { material: } \\
\text { quality }\end{array}$ & linguistic & 0.015 & benefits & Quality of raw material \\
\hline 2 & $\begin{array}{l}\text { Raw material \& product: raw } \\
\text { material: Confidence }\end{array}$ & linguistic & 0.009 & benefits & Confidence in supply \\
\hline 3 & $\begin{array}{l}\text { Raw material \& product: } \\
\text { raw material: distance: Now }\end{array}$ & deterministic & 0.006 & costs & $\begin{array}{l}\text { Supply distance (present, } \\
\text { Kilometer) }\end{array}$ \\
\hline 4 & $\begin{array}{l}\text { Raw material \& product: } \\
\text { raw material: distance: Future }\end{array}$ & deterministic & 0.002 & costs & $\begin{array}{l}\text { Supply distance (future, } \\
\text { Kilometer) }\end{array}$ \\
\hline 5 & $\begin{array}{l}\text { Raw material \& product: } \\
\text { final product: Market capacity }\end{array}$ & linguistic & 0.073 & benefits & Sale amount of product \\
\hline 6 & $\begin{array}{l}\text { Raw material \& product: } \\
\text { raw material: Quantity }\end{array}$ & linguistic & 0.015 & benefits & $\begin{array}{l}\text { Quantity of raw material } \\
\text { (inside the region, M3) }\end{array}$ \\
\hline 7 & $\begin{array}{l}\text { Raw material \& product: } \\
\text { final product: distance from } \\
\text { market: } \\
\text { outside }\end{array}$ & deterministic & 0.004 & costs & $\begin{array}{l}\text { Distance from market } \\
\text { (Kilometer) }\end{array}$ \\
\hline 8 & $\begin{array}{l}\text { Infrastructure } \\
\text { Transportation network: } \\
\text { Road }\end{array}$ & linguistic & 0.028 & benefits & Transportation network (road) \\
\hline 9 & $\begin{array}{l}\text { Infrastructure } \\
\text { Transportation network: } \\
\text { Rail }\end{array}$ & linguistic & 0.014 & benefits & Transportation network (rail) \\
\hline 10 & $\begin{array}{l}\text { Infrastructure } \\
\text { Area profile } \\
\text { Average rainfall }\end{array}$ & linguistic & 0.053 & costs & $\begin{array}{l}\text { Average of rainfall in the } \\
\text { province }(\mathrm{mm})\end{array}$ \\
\hline 11 & $\begin{array}{l}\text { Infrastructure } \\
\text { Area profile } \\
\text { Amount of absorbed solar energy }\end{array}$ & linguistic & 0.159 & benefits & $\begin{array}{l}\text { Amount of absorbed solar } \\
\text { energy } \\
\text { In the province }\left(\mathrm{cal} / \mathrm{cm}^{2}\right) \text { in } \\
\text { the province }\end{array}$ \\
\hline 12 & $\begin{array}{l}\text { Infrastructure } \\
\text { Area profile } \\
\text { Relative humidity } \\
\end{array}$ & linguistic & 0.053 & costs & $\begin{array}{l}\text { Ralative humidity in the } \\
\text { province }(\%)\end{array}$ \\
\hline 13 & $\begin{array}{l}\text { Infrastructure } \\
\text { Investment }\end{array}$ & linguistic & 0.033 & benefits & Capital absorption \\
\hline 14 & $\begin{array}{l}\text { Infrastructure } \\
\text { Background of industry } \\
\text { Energy }\end{array}$ & linguistic & 0.028 & benefits & Industry background \\
\hline 15 & $\begin{array}{l}\text { Infrastructure } \\
\text { Background of industry } \\
\text { Lateral industries }\end{array}$ & linguistic & 0.037 & benefits & $\begin{array}{l}\text { Background of industry } \\
\text { Lateral industries }\end{array}$ \\
\hline 16 & $\begin{array}{l}\text { Infrastructure: } \\
\text { Background of industry: } \\
\text { Services }\end{array}$ & linguistic & 0.013 & benefits & $\begin{array}{l}\text { Background of industry: } \\
\text { Services }\end{array}$ \\
\hline 17 & $\begin{array}{l}\text { Infrastructure: } \\
\text { Background of industry: } \\
\text { Competitors }\end{array}$ & linguistic & 0.018 & costs & Competitors in the province \\
\hline 18 & $\begin{array}{l}\text { Human \& technical: } \\
\text { Human: } \\
\text { Training centers availability }\end{array}$ & linguistic & 0.01 & benefits & Training centers availability \\
\hline 19 & $\begin{array}{l}\text { Human \& technical: } \\
\text { Human: } \\
\text { Skilled man force availability }\end{array}$ & linguistic & 0.071 & benefits & Skilled man force availability \\
\hline 20 & $\begin{array}{l}\text { Human \& technical: } \\
\text { Human: } \\
\text { Welfare facilities }\end{array}$ & linguistic & 0.1 & benefits & Welfare facilities \\
\hline 21 & $\begin{array}{l}\text { Human \& technical: } \\
\text { Technical: } \\
\text { Technological knowledge }\end{array}$ & linguistic & 0.021 & benefits & Technological knowledge \\
\hline 22 & $\begin{array}{l}\text { Economical: } \\
\text { Costs: } \\
\text { Man force cost }\end{array}$ & linguistic & 0.002 & costs & $\begin{array}{l}\text { Man force costs (Monthly } \\
\text { wage: Rial) }\end{array}$ \\
\hline 23 & $\begin{array}{l}\text { Economical } \\
\text { Costs } \\
\text { Price of land }\end{array}$ & linguistic & 0.02 & costs & Price of land (per $\mathrm{m}^{2}:$ Rial) \\
\hline 24 & $\begin{array}{l}\text { Economical: } \\
\text { Costs: } \\
\text { Cost purchasing of raw material }\end{array}$ & linguistic & 0.071 & costs & $\begin{array}{l}\text { Cost purchasing of raw } \\
\text { material }\end{array}$ \\
\hline 25 & Economical: & linguistic & 0.016 & costs & Storage cost \\
\hline
\end{tabular}




\begin{tabular}{|c|c|c|c|c|c|}
\hline & $\begin{array}{l}\text { Costs: } \\
\text { Storage cost }\end{array}$ & & & & (Daily: Rial) \\
\hline 26 & $\begin{array}{l}\text { Economical: } \\
\text { Costs: } \\
\text { Cost of transportation: } \\
\text { Raw material }\end{array}$ & $\begin{array}{l}\text { Triangular } \\
\text { Fuzzy }\end{array}$ & 0.026 & costs & $\begin{array}{l}\text { Cost of transportation: } \\
\text { Raw material } \\
\text { (Per10km:Rial) }\end{array}$ \\
\hline 27 & $\begin{array}{l}\text { Economical: } \\
\text { Costs: } \\
\text { Cost of transportation: } \\
\text { Final product }\end{array}$ & $\begin{array}{l}\text { Triangular } \\
\text { Fuzzy }\end{array}$ & 0.009 & costs & $\begin{array}{l}\text { Cost of transportation: } \\
\text { Final product } \\
\text { (Per 10km:Rial) }\end{array}$ \\
\hline 28 & $\begin{array}{l}\text { Economical: } \\
\text { Granted facilities }\end{array}$ & linguistic & 0.142 & benefits & Granted facilities \\
\hline 29 & $\begin{array}{l}\text { Rules \& regulations: } \\
\text { Tax rate }\end{array}$ & linguistic & 0.02 & costs & $\begin{array}{l}\text { regulations: } \\
\text { Tax rate } \\
\text { (Annual :\%) }\end{array}$ \\
\hline
\end{tabular}

The software is also capable of generating detailed description and analysis of the decision problem in an intelligent report form. The weights are calculated as follows:

The questionnaires of the data for the attributes were distributed to the selected locations and then collected as the source of information. Some of the data were linguistic type while some of them were deterministic. Some kinds of attributes were divided into cost or benefits, depending on being considered as desirable or undesirable by the decision makers (Table 1). For applying FDM software, the linguistic data were converted to fuzzy data (Table 2). A sample of the attributes is shown in Fig. 3.

The Triangular Fuzzy data is in the form of $m, a$ and $b$, where ' $m$ ' means an approximate value, ' $a$ ' the positive tolerance of ' $m$ ' and ' $b$ ' represents the negative tolerance of ' $m$ '. These results in a matrix of $31^{*} 9$ has been presented in the attachment (Attachment 1 ).

In the next step, the fuzzy numbers are converted into real numbers by using de fuzzification methods. Then, the matrices are normalized to do away with dimensions of indicators and their coefficients are multiplied by the related vector. We can obtain the radius value of any alternatives in an ' $n$ ' dimensional space (where $n$ means number of indicators) by finding ideally positive and negative solutions. The final advantage of each alternative is because of its relative proximity to positive ideal response (Hwang \& Yoon, 1981).

Figure 3: Description of the criteria in FDM (A sample)

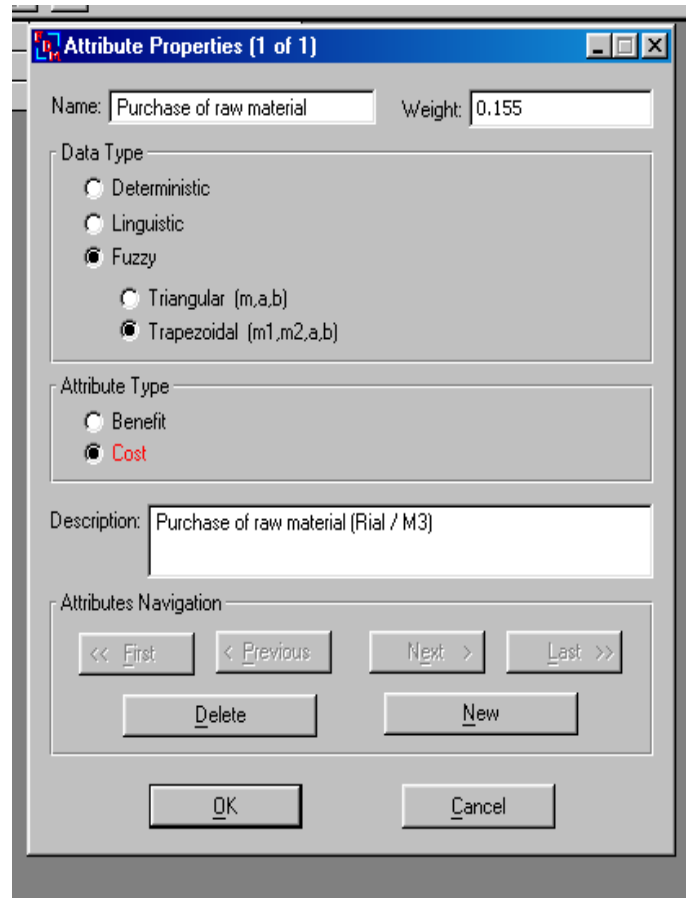


Table 2: The conversion of linguistic data to fuzzy data

\begin{tabular}{|c|c|}
\hline Linguistic data & Fuzzy data(m1, m2, a, b) \\
\hline Very low & $0,0.1,0,0.1$ \\
\hline Low & $0.2,0.2,0.1,0.1$ \\
\hline Fairly low & $0.3,0.4,0.1,0.1$ \\
\hline Average & $0.5,0.5,0.1,0.1$ \\
\hline Fairly high & $0.6,0.7,0.1,0.1$ \\
\hline High & $0.8,0.8,0.1,0.1$ \\
\hline Very high & $0.9,1,0.1,0$ \\
\hline
\end{tabular}

\section{Results and conclusion}

The 9 location candidates were ranked using FDM software and the ranking result is presented in Table 3.

Table 3: Final outcome
\begin{tabular}{|c|c|c|}
\hline Rating & Priority & Province \\
\hline 2 & 85.71 & Tehran \\
\hline 1 & 88.83 & Qom \\
\hline 5 & 72.97 & Alborz \\
\hline 9 & 47.66 & Qazvin \\
\hline 7 & 63.29 & Markazi \\
\hline 4 & 74.91 & Mazandaran \\
\hline 8 & 61.44 & Fars \\
\hline 6 & 70.86 & Esfahan \\
\hline 3 & 76.48 & Khorasan \\
\hline
\end{tabular}

\subsection{Criteria}

\subsubsection{Amount of absorbed solar energy as the highest priority criteria}

The result (Table1) shows that below average temperature criteria (0.159), granted facilities, market capacity, labor force availability and price of raw material, have highest priority for site selection of solar wood drying units respectively.

Radiation is amount of energy of electromagnetic on area unit per unit of time which has been named as flux. Solar energy is an opportunity which there is extended programs for developing its application in the world. Programming for solar energy application is a capacity building for using a very large resource which is not comparable with other current energy resources because amount of solar energy is more than several times of energy consumption which man uses energy throughout the year, that is accessible (solar energy) on the earth per hour.

The application of enormous solar energy resources for electricity energy production, dynamic usage, heating generation for areas and buildings, drying agricultural products, chemical changes and so on, are the strategies which have been started in former years. The amount of solar energy obtained from sun radiation in one point of earth area throughout the year, depends on the intensity and duration of sun radiation in that region.

Results of the interview with the experts indicated that maximum radiation of sun throughout the year in the region is the most important criteria for site selection of solar wood drying units. Iran has various climates. Air temperatures, humidity, radiation of sun, rate of rain are different in the regions. Hence it will be logical that the average of air temperature or incoming energy from the sun in each region has the highest priority for site selection of solar wood drying units.

\subsection{Alternatives}

\subsubsection{Prioritizing items using TOPSIS}

Qom province (see Table3) is not only the closest province to the largest furniture consumption market of Iran but also has appropriate infrastructure similar ideal transportation network between Qom and Tehran, many equipped industrial towns with low distance to Tehran, 
extended facilities and preferences for investment attractions. For these reasons Qom province actually has changed the largest regional industrial town near to Tehran. Permitted distance for establishing industrial units from Tehran as center of Iran is more than $120 \mathrm{~km}$; in this regard Qom province obtains higher priority to establish industrial units. According to the existence of skillful man force criteria, Qom province has good background in wood industry and in this province access to skillful and knowledgeable man force has proper situation.

In this province man force cost and price of land for establishing a factory is lower than Tehran. Average of air temperature or incoming energy from the sun in Qom province is favorite situation so that division of different regions of Iran regarding average of air temperature shows this province is located in the region with high radiation of sun. Accordingly the selection of Qom province as an appropriate alternative for establishing solar wood drying units is logical and justified.

\section{Appendix A. Supplementary material}

Supplementary data associated with this article can be found, in the online version, at https://dx.doi.org/10.14254/jems.2017.2-2.2

\section{Funding}

The authors received no direct funding for this research.

\section{Citation information}

Azizi, M. (2017). Strategic model for location selection of solar wood drying by applying TOPSIS. Economics, Management and Sustainability, 2(2), 15-23. doi:10.14254/jems.2017.2-2.2.

\section{References}

Azizi, M. (2012). A decision making model regarding wood panel selection. International Journal of Analytic Hierarchy Process (IJAHP), 4(2).

Desch, H. E., \& Dinwoodie, J. M. (1996). Timber: Structure, Properties, Conversion and use. London: Macmillan Press Ltd.

Helwa, N. H., Khater, H. A., Enayet, M. M., \& Hashish, M. I. (2004). Experimental evaluation of solar kiln for drying wood. Drying technology, 22(4), 703-717.

Hwang, C. L., \& Yoon, K. (1981). Multiple Attribute Decision Making. Springer Verlag.

Ishizaka, A., \& Labib, A. (2011). Review of the main developments in the analytic hierarchy process. Expert systems with applications, 38(11), 14336-14345.

McCauley, C. K., \& Caulfield, J. P. (1990). Using mixed-integer programming to determine the optimal location for an oriented strandboard plant in Alabama. Forest products journal, 40(2), 39-44.

Memariani, A. (2000). FDM Manual. Tarbiat Modarres University, 11-24.

Michael, J. H., Teitel, J., \& Granskog, J. E. (1998). Production facility site selection factors for Texas value-added wood producers. Forest products journal, 48(7/8), 27-32.

Scientific, technical and statistical information provided by SANA (renewable energy organization of Iran). Retrieved from http://www.suna.org.ir/fa/home.

Wilson, J. (2006). Solar drying kilns: A cost effective and efficient way to take green board to usable lumber. Popular wood working, 74-79. Retrieved from http://washtenawcd.org/downloads/solarkiln. 


\section{Attachment 1}

\begin{tabular}{|l|c|c|c|c|}
\hline & $\begin{array}{c}\text { Quality of raw } \\
\text { material }\end{array}$ & $\begin{array}{c}\text { Confidence of raw } \\
\text { material }\end{array}$ & $\begin{array}{c}\text { Distance of raw } \\
\text { material km }\end{array}$ & $\begin{array}{c}\text { Distance raw } \\
\text { material future km }\end{array}$ \\
\hline Alborz & very high & very high & 150 & 50 \\
\hline Fars & low & medium & 250 & 150 \\
\hline Isfahan & medium & high & 250 & 200 \\
\hline Khorasan & high & high & 150 & 100 \\
\hline Markazi & medium & medium & 250 & 50 \\
\hline Mazandaran & very high & very high & 50 & 50 \\
\hline Qazvin & medium & medium & 250 & 150 \\
\hline Qom & very high & very high & 50 & 50 \\
\hline Tehran & very high & very high & 50 & 50 \\
\hline
\end{tabular}

\begin{tabular}{|l|c|c|c|c|c|}
\hline & Market capacity & $\begin{array}{c}\text { Quality of raw } \\
\text { material }\end{array}$ & $\begin{array}{c}\text { Distance from } \\
\text { market km }\end{array}$ & $\begin{array}{c}\text { Transportation } \\
\text { road }\end{array}$ & $\begin{array}{c}\text { Transportation } \\
\text { rail }\end{array}$ \\
\hline Alborz & high & high & 50 & high & medium \\
\hline Fars & low & low & 350 & high & medium \\
\hline Isfahan & high & low & 50 & very high & very high \\
\hline Khorasan & very high & low & 50 & very high & very high \\
\hline Markazi & medium & medium & 350 & high & high \\
\hline Mazandaran & medium & very high & 350 & high & high \\
\hline Qazvin & low & low & 250 & medium & low \\
\hline Qom & very high & very high & 70 & very high & very high \\
\hline Tehran & very high & very high & 50 & very high & very high \\
\hline
\end{tabular}

\begin{tabular}{|l|c|c|c|c|}
\hline & $\begin{array}{c}\text { Background } \\
\text { lateral industries }\end{array}$ & $\begin{array}{c}\text { Background } \\
\text { services }\end{array}$ & Background competitors & $\begin{array}{c}\text { Training center } \\
\text { availability }\end{array}$ \\
\hline Alborz & high & high & medium & high \\
\hline Fars & low & low & low & low \\
\hline Isfahan & medium & medium & medium \\
\hline Khorasan & high & high & low & very high \\
\hline Markazi & medium & low & low & high \\
\hline Mazandaran & medium & medium & high & low \\
\hline Qazvin & low & medium & low & very high \\
\hline Qom & very high & very high & low & very high \\
\hline Tehran & very high & very high & medium &
\end{tabular}

\begin{tabular}{|l|c|c|c|c|}
\hline & $\begin{array}{c}\text { Skill man force } \\
\text { availability }\end{array}$ & $\begin{array}{c}\text { Human welfare } \\
\text { facility }\end{array}$ & $\begin{array}{c}\text { Technical technological } \\
\text { knowledge }\end{array}$ & Man force cost \\
\hline Alborz & high & medium & medium & medium \\
\hline Fars & medium & high & medium & medium \\
\hline Isfahan & medium & medium & medium & medium \\
\hline Khorasan & high & very high & high & medium \\
\hline Markazi & medium & high & medium & medium \\
\hline Mazandaran & high & high & medium & medium \\
\hline Qazvin & low & high & very high & medium \\
\hline Qom & very high & very high & very high & Relatively high \\
\hline Tehran & very high & very high &
\end{tabular}




\begin{tabular}{|l|c|c|c|c|}
\hline & Price of land & $\begin{array}{c}\text { Purchase cost } \\
\text { raw material }\end{array}$ & Storage cost & $\begin{array}{c}\text { Transportation raw } \\
\text { material cost }\end{array}$ \\
\hline Alborz & low & medium & low & $\begin{array}{c}\text { m:450000 a:50000 b } \\
50000\end{array}$ \\
\hline Fars & very low & medium & very low & $\begin{array}{c}\text { m:450000 a:50000 b } \\
50000\end{array}$ \\
\hline Isfahan & medium & medium & low & $\begin{array}{c}\text { m:450000 a:50000 b } \\
50000\end{array}$ \\
\hline Khorasan & medium & medium & low & $\begin{array}{c}\text { m:45000 a:50000 b } \\
50000\end{array}$ \\
\hline Markazi & very low & medium & very low & $\begin{array}{c}\text { m:550000 a: } 10000 \mathrm{~b} \\
20000\end{array}$ \\
\hline Mazandaran & low & low & very low & $\begin{array}{c}\mathrm{m}: 150000 \mathrm{a}: 50000 \\
\mathrm{~b}: 50000\end{array}$ \\
\hline Qazvin & very low & high & very low & $\begin{array}{c}\mathrm{m}: 450000 \mathrm{a}: 50000 \mathrm{~b} \\
50000\end{array}$ \\
\hline Qom & very low & medium & medium & $\begin{array}{c}\mathrm{m}: 250000 \mathrm{a}: 50000 \\
\mathrm{~b}: 50000\end{array}$ \\
\hline Tehran & medium & medium & medium & $\begin{array}{c}\mathrm{m}: 350000 \mathrm{a}: 50000 \\
\mathrm{~b}: 50000\end{array}$ \\
\hline
\end{tabular}

\begin{tabular}{|l|l|c|c|c|}
\hline & \multicolumn{1}{|c|}{$\begin{array}{c}\text { Transportation final } \\
\text { product cost }\end{array}$} & Granted facility & $\begin{array}{c}\text { Regulation tax } \\
\text { rate }\end{array}$ & $\begin{array}{c}\text { Regulation permissible } \\
\text { distance }\end{array}$ \\
\hline Alborz & $\mathrm{m}: 450000 \mathrm{a}: 50000 \mathrm{~b}: 50000$ & high & medium & high \\
\hline Fars & $\mathrm{m}: 250000 \mathrm{a}: 50000 \mathrm{~b}: 50000$ & high & medium & high \\
\hline Isfahan & $\mathrm{m}: 450000 \mathrm{a}: 50000 \mathrm{~b}: 50000$ & high & medium & high \\
\hline Khorasan & $\mathrm{m}: 450000 \mathrm{a}: 50000 \mathrm{~b}: 50000$ & medium & medium & high \\
\hline Markazi & $\mathrm{m}: 450000 \mathrm{a}: 50000 \mathrm{~b}: 50000$ & high & medium & high \\
\hline Mazandaran & $\mathrm{m}: 350000 \mathrm{a}: 50000 \mathrm{~b}: 50000$ & high & medium & high \\
\hline Qazvin & $\mathrm{m}: 450000 \mathrm{a}: 50000 \mathrm{~b}: 50000$ & medium & medium & high \\
\hline Qom & $\mathrm{m}: 350000 \mathrm{a}: 50000 \mathrm{~b}: 50000$ & high & medium & high \\
\hline Tehran & $\mathrm{m}: 350000 \mathrm{a}: 50000 \mathrm{~b}: 50000$ & high & relatively high & very high \\
\hline
\end{tabular}

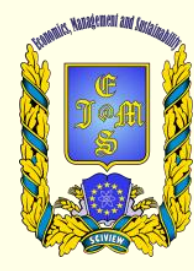

() 2016-2017, Economics, Management and Sustainability. All rights reserved.

This open access article is distributed under a Creative Commons Attribution (CC-BY) 4.0 license.

Share - copy and redistribute the material in any medium or format Adapt - remix, transform, and build upon the material for any

purpose, even commercially.

The licensor cannot revoke these freedoms as long as you follow the license terms.

Under the following terms:

Attribution - You must give appropriate credit, provide a link to the license, and indicate if changes were made.

You may do so in any reasonable manner, but not in any way that suggests the licensor endorses you or your use.

No additional restrictions

You may not apply legal terms or technological measures that legally restrict others from doing anything the license permits.

Economics, Management and Sustainability (ISSN: 2520-6303) is published by Scientific Publishing House "CSR",

Poland, EU and Scientific Publishing House "SciView", Poland

Publishing with JEMS ensures:

- Immediate, universal access to your article on publication

- High visibility and discoverability via the JEMS website

- Rapid publication

- Guaranteed legacy preservation of your article

- Discounts and waivers for authors in developing regions

Submit your manuscript to a JEMS at https://jems.sciview.net or submit.jems@sciview.net

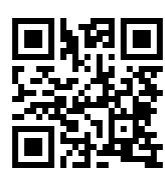

